\title{
Recurrence of COVID-19 related symptoms and viral detection in a patient discharged after complete recovery and test negativization
}

\author{
Chiara Vassallo, Francesca Pupo, Luca Marri, Chiara Schiavi, Francesca Giusti, Monica Greco, Simone Negrini, \\ Raffaele De Palma, Andrea Guastalla \\ Department of Clinical Immunology, IRCCS-San Martino University Hospital, University of Genoa, Italy
}

\begin{abstract}
Since the novel coronavirus disease 2019 (COVID-19) has been declared a pandemic, the possibility of recurrence of the disease after recovery has become a debated issue. We report a case of an 84-years-old male patient who was admitted to our hospital for dyspnea and fever. Lab and clinical workout showed that he had COVID-19. After a full recovery of symptoms and a double negative nasopharyngeal swab of severe acute respiratory syndrome-related coronavirus 2 (SARS-CoV-2) by realtime polymerase chain reaction assay, he was discharged from the hospital. One month later, he developed dyspnea and fever again with lung involvement. Surprisingly, the nasopharyngeal swab of SARS-CoV-2 was positive. Since he denied contacts with confirmed or suspected cases of COVID-19, he probably experienced a reactivation of a persistent infection. The failed eradication of the virus could depend on both virus' escape mechanisms and dysfunctional immune response. Further studies are needed to confirm the hypothesis of viral reactivation and identify signs of an incomplete clearance.
\end{abstract}

\section{Case Report}

Starting in December 2019, the outbreak of the novel coronavirus disease 2019 (COVID-19) has be-

Correspondence: Chiara Vassallo, Department of Clinical Immunology, IRCCS-San Martino University Hospital, University of Genoa, Largo Rosanna Benzi 10, 16132 Genoa, Italy. Fax:+39.010.5556586. E-mail: chiaravsl@gmail.com

Key words: COVID-19; viral test; pneumonia; viral clearance.

Contributions: all the authors participated in the study conception; $\mathrm{LM}, \mathrm{CS}, \mathrm{FG}$ and $\mathrm{MG}$ acquired data; $\mathrm{CV}$ and $\mathrm{FP}$ took the lead in drafting the manuscript; SN, RDP, AG provided a critical revision of the manuscript. All authors discussed the results and contributed to the final manuscript.

Conflict of interests: the authors declare no potential conflict of interests.

Informed consent: written informed consent was obtained from the patient of the study.

Received for publication: 18 October 2020.

Accepted for publication: 27 October 2020.

This work is licensed under a Creative Commons Attribution NonCommercial 4.0 License (CC BY-NC 4.0).

${ }^{\circ}$ Copyright: the Author(s), 2021

Licensee PAGEPress, Italy

Italian Journal of Medicine 2021; 15:67-70

doi:10.4081/itjm.2021.1393 come a global health concern, as World Health Organization (WHO) stated on $30^{\text {th }}$ January 2020 . Since $20^{\text {th }}$ February this serious illness spread all over Italy. Our region, Liguria, experienced a high/moderate spreading: to date, eighteen thousand cases were reported, with an incidence of 1004 cases $/ 100,000$ resident persons and about 1600 deaths. We report a case of an 84years-old male patient admitted to our hospital on $14^{\text {th }}$ March for fever, cough, and progressive dyspnea since $1^{\text {st }}$ March. He had hypertension, dyslipidemia, glaucoma, and mild chronic kidney failure and he was a former smoker (15 packs/year). His chronic therapy included ramipril and atorvastatin. The chest $\mathrm{x}$-ray reported bilateral consolidations in the right lower and in the left medium and lower fields (Figure 1, Panel A). Blood tests revealed leukopenia and lymphopenia (with normal CD4/CD8 ratio), acute kidney failure and abnormal creatine phosphokinase, lactate dehydrogenase, fibrinogen, $\mathrm{D}$-dimer, reactive $\mathrm{C}$ protein, and interleukin-6 (Table 1). The nasopharyngeal swab of severe acute respiratory syndrome-related coronavirus 2 (SARS-CoV-2) by real-time polymerase chain reaction (RT-PCR) assay was positive. The serological test of SARS-CoV-2 showed positive immunoglobulin (Ig)G and borderline IgM. The patient was treated with antimicrobial therapy according to the hospital guideline, including hydroxychloroquine (400 mg bid), darunavir ( $800 \mathrm{mg} /$ die), ritonavir (100 $\mathrm{mg} / \mathrm{die})$, oseltamivir $(75 \mathrm{mg} / \mathrm{die})$, intravenous ceftarolin (400 mg bid) and prophylactic enoxaparin.

Further, he underwent non-invasive ventilation with continuous positive airway pressure in concomi- 
tance with intravenous methylprednisolone $(1 \mathrm{mg} / \mathrm{kg})$. His clinical condition slowly improved. Two nasopharyngeal swab tests of SARS-CoV-2 performed on $18^{\text {th }}$ and $23^{\text {rd }}$ March resulted negative. After one week free of symptoms, the patient was discharged on $1^{\text {st }}$ April, according to the local criteria of discharge (two negative nasopharyngeal swab RT-PCR of SARS-CoV-2 and the absence of symptoms) and consigned to quarantine at home. Hydroxychloroquine was continued until $5^{\text {th }}$ April while enoxaparin 2000 UI was administered during all the quarantine. On $22^{\text {nd }}$ April, he developed fever (up to $38^{\circ} \mathrm{C}$ ) and desaturation, and he was admitted to our hospital again. The chest X-ray revealed persistent bilateral consolidations (Figure 1, Panel B). Blood tests showed a worsening of leukopenia and lymphopenia, abnormal lactate dehydrogenase, inflammatory indices, and coagulation profile. Urinary antigens of Streptococcus pneumoniae and Legionella were negative; blood cultures for aerobic and anaerobic bacteria excluded a blood stream infection. On $25^{\text {th }}$ April, the nasopharyngeal swab test of SARS-CoV-2 by RT-PCR assay resulted positive. The serological test for SARCoV-2 showed positive $\mathrm{IgG}$ and negative IgM. A computed tomographic scan of the lungs showed bilateral ground-glass opacities, pleural effusion, mediastinal lymphadenopathies. He was treated with supplemental oxygen, intravenous methylprednisolone (1 $\mathrm{mg} / \mathrm{kg})$, intravenous immunoglobulin $(0.4 \mathrm{~g} / \mathrm{kg}$ for three days $)$, amoxicillin/clavulanate $3 \mathrm{gr} / \mathrm{die}$, prophylactic enoxaparin. The patient's clinical conditions progressively improved. On $5^{\text {th }}$ and $7^{\text {th }}$ May, the nasopharyngeal swab test of SARS-CoV-2 by RT-PCR assay was negative; then the patient was discharged.

\section{Discussion}

Many cases have been reported about the recurrence of a positive RT-PCR test of SARS-CoV-2 after discharge in different specimens (throat swab, naso/oropharyngeal swab, saliva, urine, and feces) with different temporal profiles. Usually, this occurred during the first week after discharge, and it was poorly associated with relapse of symptoms and worsening in radiological exam or laboratory test. The recurrence of viral RNA has been considered a consequence of previously false negative tests due to the low sensitivity of the method. ${ }^{1}$ Moreover, a positive test does not indicate the presence of replicating virus particles. ${ }^{2}$ However, our patient experienced a longer recovery time (almost one month) than the average of cases reported in the literature, and he developed clinical/radiological/laboratory features compatible with COVID-19. We could infer that he was facing an active infection of the virus. He denied contact with positive cases during the quarantine at home, so he probably experienced a recrudescence of a persistent infection.

In this line, Yao et al. reported the case of a 78years-old woman who turned to have viral particles in lung cell regardless of the negative detection of SARS-CoV-2 nucleic acid from nasopharyngeal swabs and the clinical and radiological recovery, to indicate that a nasopharyngeal swab negative result might not reflect the virus in lung tissue. ${ }^{3}$ Many other manuscripts reported that viral RNA can be found in different tissues at different times, indicating that the absence of virus detection in a site does not rule out virus persistence and replication in a different organ.

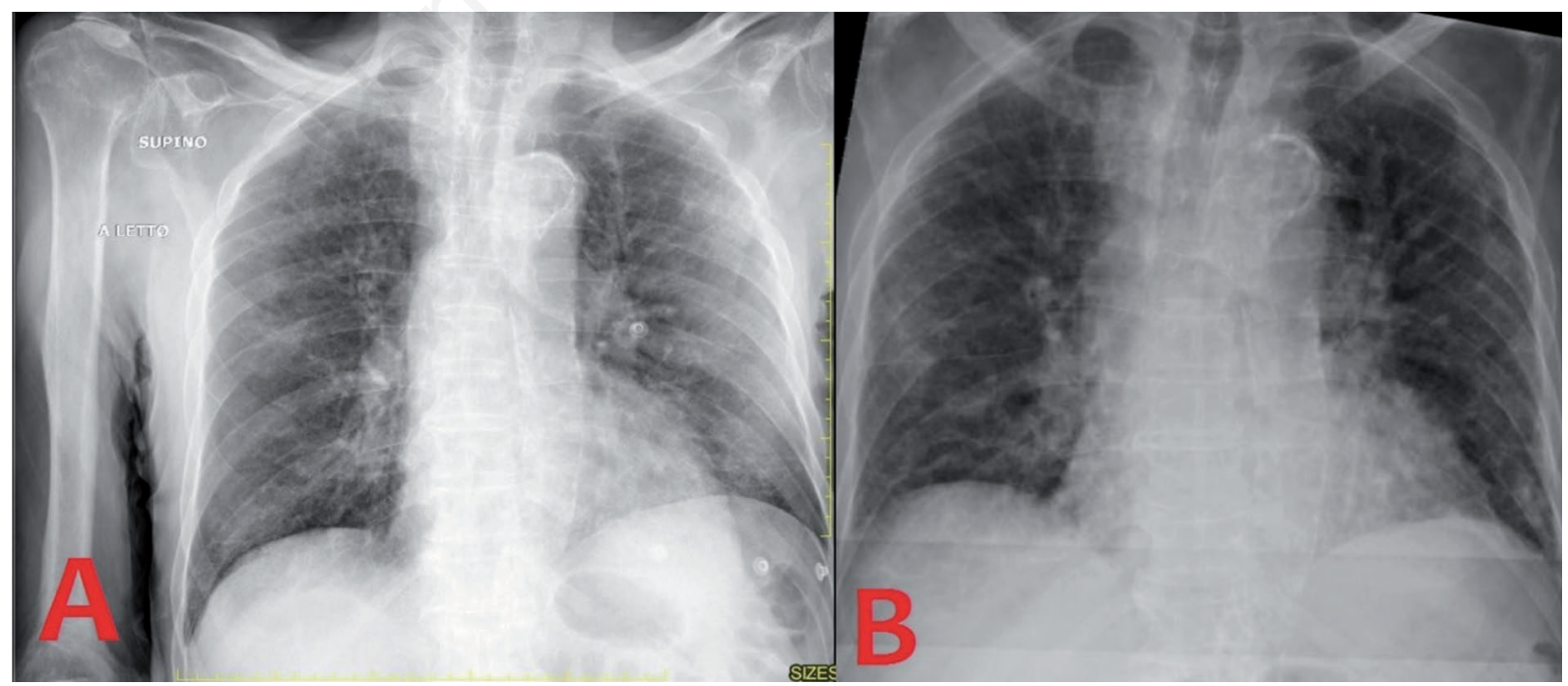

Figure 1. The radiological course of severe acute respiratory syndrome-related coronavirus 2 infection. A) Bedside chest X-ray performed on $14^{\text {th }}$ March showing consolidations in the right lower and in the left medium and lower fields. B) Chest X-ray performed on $24^{\text {th }}$ April, one month after the first recovery, showing persistent bilateral lesions. 
Furthermore, an independent replication of the virus in different body tissue has been demonstrated. ${ }^{2}$ This could depend on the interactions between the virus and immune system. As for other viruses, SARS$\mathrm{CoV}-2$ could impair an efficient immune response in several ways. Among the escape mechanisms, it has been shown that this virus inhibits the interferon-1 pathway, screwing the immune response. ${ }^{4} \mathrm{~A}$ low viral load could also contribute to persistence and immune evasion..$^{5}$ On the other hand, a dysfunctional immune response could not be able to eradicate the pathogen, as happened in people aged over 60 and people with comorbidities. For example, an aging lung microen- vironment could impair immune responses at different levels. ${ }^{6}$ In this line, the duration and recurrence of viral RNA detection turned out to correlate with lymphocyte count. ${ }^{7,8}$ Our patient developed a seroconversion on day 15 since the symptoms' onset. The absence of IgM during the relapse of the disease could be due to the low intrinsic sensitivity of antibodies' detection method, as previously described for SARS-CoV-1 and Middle East respiratory syndrome. ${ }^{9}$ Antibodies produced against SARS-CoV2 seem to mediate virus neutralization in most individuals; however, their efficacy and duration remain to be clarified.

Table 1. The laboratory course of severe acute respiratory syndrome-related coronavirus 2 infection. Summary of the blood tests and arterial blood gas tests performed during the first (14 $4^{\text {th }}$ March-1 ${ }^{\text {st }}$ April) and second (24 ${ }^{\text {th }}$ April-8 ${ }^{\text {th }}$ May) $^{-}$ hospitalization.

\begin{tabular}{|c|c|c|c|c|c|c|c|}
\hline & & \multicolumn{3}{|c|}{ First hospitalization } & \multicolumn{3}{|c|}{ Second hospitalization } \\
\hline & & $1^{\text {st }}$ day & $7^{\text {th }}$ day & $14^{\text {th }}$ day & $1^{\text {st }}$ day & $7^{\text {th }}$ day & $14^{\text {th }}$ day \\
\hline \multirow[t]{21}{*}{ Blood tests } & PCR (0.05-5 mg/L) & 41 & 9 & 0 & 24.8 & 8.4 & 0 \\
\hline & IL-6 (<3.4 ng/L) & 253 & 105 & 50.8 & 259 & - & - \\
\hline & PCT (0-0.25 mcg/L) & 0.22 & 0.08 & 0.34 & 0.38 & 0.1 & 0.07 \\
\hline & Ferritin (30-400 ng/L) & - & 1260 & 593 & 414 & 549 & - \\
\hline & WBC $\left(4500-9800 \times 10^{6} / \mathrm{L}\right)$ & 4460 & 4500 & 5810 & 4480 & 7240 & 5770 \\
\hline & NEU $\left(1800-7800 \times 10^{6} / \mathrm{L}\right)$ & 3000 & 4000 & 3960 & 2200 & 5500 & 3750 \\
\hline & LYM $\left(1100-4800 \times 10^{6} / \mathrm{L}\right)$ & 700 & 200 & 1040 & 900 & 1620 & 1360 \\
\hline & $\mathrm{Hb}(12.0-16.0 \mathrm{~g} / \mathrm{dL})$ & 14.7 & 10.9 & 12 & 9.3 & 10 & 10.6 \\
\hline & $\operatorname{PLT}\left(130-430 \times 10^{9} / \mathrm{L}\right)$ & 172 & 342 & 184 & 303 & 386 & 268 \\
\hline & LDH (135-225 U/L) & 492 & 298 & 296 & 246 & 271 & 240 \\
\hline & CPK (39-190 U/L) & 215 & 81 & 81 & 62 & 32 & 30 \\
\hline & GPT $(0-40 \mathrm{U} / \mathrm{L})$ & 47 & 47 & 25 & 18 & 43 & 76 \\
\hline & GOT $(0-40 \mathrm{U} / \mathrm{L})$ & 52 & 36 & 19 & 16 & 33 & 49 \\
\hline & GGT (11-50 U/L) & 22 & 17 & 19 & 10 & 13 & 21 \\
\hline & $\operatorname{ALP}(50-116 \mathrm{U} / \mathrm{L})$ & 78 & 48 & 47 & 56 & 41 & 42 \\
\hline & Bilirubin $(0.20-1.20 \mathrm{mg} / \mathrm{dL})$ & 0.51 & 0.27 & 0.34 & 0.27 & 0.32 & 0.22 \\
\hline & D-dimer $(0-500 \mathrm{mcg} / \mathrm{L})$ & 1460 & 1115 & 3516 & 1783 & 1876 & 1271 \\
\hline & Fibrinogen $(2.00-4.00 \mathrm{~g} / \mathrm{L})$ & 4.7 & 3.99 & 2.67 & 3.64 & 2.94 & 2.7 \\
\hline & Creatinine $(0.67-1.17 \mathrm{mg} / \mathrm{dL})$ & 2 & 2.5 & 1.8 & 1.3 & 1.1 & 1.3 \\
\hline & NT-proBNP (ng/L) & 676 & - & - & 3020 & 6730 & 711 \\
\hline & $\operatorname{TnI}(0-0.046 \mathrm{mcg} / \mathrm{L})$ & 0.02 & - & - & $<0.015$ & 0.02 & $<0.015$ \\
\hline \multirow[t]{5}{*}{ Arterial blood gas tests } & $\mathrm{pH}(7.35-7.45)$ & 7.42 & 7.44 & 7.35 & 7.42 & 7.36 & 7.37 \\
\hline & $\mathrm{pO}_{2}(60-100 \mathrm{mmHg})$ & 62.5 & 200 & 75 & 54.9 & 100 & 67 \\
\hline & $\mathrm{pCO}_{2}(35-45 \mathrm{mmHg})$ & 28.5 & 25.9 & 27 & 29.8 & 32.9 & 34.5 \\
\hline & $\mathrm{FiO}_{2}(\%)$ & 80 & 60 & 21 & 21 & 31 & 21 \\
\hline & $\mathrm{p} / \mathrm{f}$ & 78 & 333 & 357 & 261 & 323 & 319 \\
\hline
\end{tabular}

PCR, polymerase chain reaction; IL-6, interleukin 6; PCT, procalcitonin; WBC, white blood cells count; LYM, lymphocytes; Hb, hemoglobin; PLT, platelets; LDH lactate dehydrogenase; CPK, creatine phosphokinase; GPT, glutamic pyruvic transaminase; GOT, glutamic-oxaloacetic transaminase; GGT, gamma-glutamyl transpeptidase; ALP, alkaline phosphatase; NT-proBNP, N-terminal-proB-type natriuretic peptide; TnI, troponin I; $\mathrm{pO}_{2}$, partial pressure of oxygen; $\mathrm{pCO}_{2}$, partial pressure of carbon dioxide; FiO ${ }_{2}$, fraction of inspired oxygen; $p$ f, ratio of partial pressure of oxygen to fraction of inspired oxygen. 


\section{Conclusions}

We report a case of COVID-19 peculiar for the long recovery period and the following recurrence of positive RT-PCR of SARS-CoV-2 RNA and respiratory disease symptoms. We speculate that this is an atypical disease course due to a re-replication of virus that was not completely cleared after the first infection. Virus persistence may depend on both virus mechanisms of immune evasion and dysfunctional immune response consequent to the age and the comorbidities of our patient. Further studies are needed to confirm this hypothesis and to identify the signs of an incomplete clearance.

\section{References}

1. Nandini S, Sundararaj SJ, Akihide R. Interpreting diagnostic test for SARS-COV-2. JAMA 2020;323: 2249-51.

2. Wölfel R, Corman VM, Guggemos W, et al. Virological assessment of hospitalized patients with COVID-19. Nature 2020;581:465-9.

3. Yao X, He Z, Li T, et al. Pathological evidence for residual SARS-CoV2 in pulmonary tissues of a ready-fordischarge patient. Cell Res 2020;30:541-3.

4. Vabret N, Britton GJ, Gruber C, et al. Immunology of COVID-19: current state of the science. Immunity 2020;52:910-41

5. Yang J-R, Deng D-T, Wu N, et al. Persistent viral RNA positivity during the recovery period of a patient with SARS-CoV-2 infection. J Med Virol 2020;1-3 [Epub ahead of print].

6. Tay MZ, Poh CM, Rénia L, et al. The trinity of COVID19: immunity, inflammation and intervention. Nat Rev Immunol 2020;20:363-74.

7. Ling Y, Xu S-B, Lin Y-X, et al. Persistence and clearance of viral RNA in 2019 novel coronavirus disease rehabilitation patients. Chin Med J 2020;133:1039-43.

8. Yuan J, Kou S, Liang Y, et al. Polymerase chain reaction assays reverted to positive in 25 discharged patients with COVID-19. Clin Infect Dis 2020; ciaa398.

9. Hu Q, Cui X, Liu X, et al. The production and clinical implications of SARS-CoV-2 antibodies; 2020. Available from: https://ssrn.com/abstract=3576845; http://dx. doi.org/10.2139/ssrn.3576845 